\title{
JORGE LUÍS BORGES
}

\section{ETNOGRAFEN*}

Historien blev refereret for mig i Texas, men var foregået i en anden stat. Den har en enkelt hovedperson, bortset fra at personerne i enhver historie er tusinder, synlige og usynlige, levende og døde. Jeg tror nok, han hed Fred Murdock. Han var høj på amerikansk vis, hverken lys eller mørk, med skarpskåren profil og af meget få ord. Der var intet specielt ved ham, ikke engang denne påtagne egenart, som er karakteristisk for unge mennesker. Han var naturligt ærbødig og havde endnu ikke mistet troen på bøger eller på dem, som skriver bøger. Han havde den alder, hvor mennesket endnu ikke ved, hvem det er, og er parat til at hengive sig til det, som tilfældet bringer; hvad enten det måtte være perserens mystik, ungarerens mystiske oprindelse, krigens eller algebraens eventyr, puritanisme eller orgier. På universitetet rådede man ham til at studere indianske sprog. Der findes esoteriske riter, som stadig praktiseres af visse stammer vestpå; hans professor, en mand op i årene, foreslog ham at slå sig ned i et reservat, observere riterne og få adgang til den hemmelighed, som medicinmanden kun røber for indviede. Efter sin tilbagekomst kunne han skrive en disputats, som instituttets autoriteter så ville lade trykke. Murdock accepterede med begejstring. En af hans forfædre var faldet i grænsekrigene; hans forfædres gamle strid var nu en slags bånd. Han forudså uden tvivl de vanskeligheder, der ventede ham; han skulle få rødhuderne til at acceptere ham som en af deres egne. Han kastede sig ud i det store eventyr. I mere end to år boede han på prærien, mellem lervægge eller under åben himmel. Han stod op før daggry, lagde sig til at sove ved solnedgang, og han kom til at drømme på et sprog, der ikke var hans forfædres. Han vænnede sin gane til skarpe smagsindtryk, klædte sig i fremmedartet tøj, glemte vennerne og byen, han kom til at tænke på en måde, som hans logik afviste. I løbet af de første måneder som lærling tog han i smug notater, som han senere rev itu, måske for ikke at vække de andres mistanke, måske fordi han ikke mere fandt dem nødvendige. Efter udløbet af en vis tid, der på forhånd var bestemt for visse øvelser af moralsk og fysisk karakter, sagde præsten til ham, at han skulle huske sine drømme og betro ham dem ved daggry. Det viste sig som ventet, at han ved fuldmåne drømte om bisonokser. Han betroede disse stadigt tilbagevendende drømme til sin læremester; denne åbenbarede ham til sidst sin hemmelige lære. Uden at tage afsked med nogen tog Murdock en morgen afsted.

I byen længtes han efter hine første lange eftermiddage på prærien, hvor han dengang havde længtes efter byen. Han lagde vejen forbi professorens kontor og sagde til ham, at han kendte hemmeligheden, og at han havde besluttet ikke at afsløre den. 
„Binder Deres ed Dem?““ spurgte denne.

„Det er ikke derfor,“"sagde Murdock. „Derude lærte jeg noget, som jeg ikke kan sige.“ „Det engelske sprog er måske utilstrækkeligt?” bemærkede den anden dernæst.

„På ingen måde, hr. professor. Nu, hvor jeg kender hemmeligheden, kunne jeg udtrykke den på hundrede forskellige måder, endog indbyrdes modstridende. Jeg ved ikke rigtig, hvordan jeg skal forklare Dem, at hemmeligheden er af største betydning, og at videnskaben, vor videnskab, nu forekommer mig at være en ren banalitet.

Han tilføjede efter en pause:

„I Øvrigt betyder selve hemmeligheden ikke så meget som de veje, der førte mig til den. De veje er det nødvendigt selv at gå.“

Professoren sagde køligt:

„Jeg skal overbringe Rådet Deres beslutning. Har De planer om at slå Dem ned blandt indianerne?“

Murdock svarede:

„Nej. Måske vender jeg ikke tilbage til prærien. Det, som dens mennesker lærte mig, er gyldigt for ethvert sted og for en hvilken som helst sammenhæng."

Således forløb samtalen i hovedtræk.

Fred giftede sig, blev skilt og er nu bibliotekar ved Yale.

* Fra El Hacedor (1960), Emecé Editores S.A., Buenos Aires, Argentina.

Tidsskriftet Antropologi takker forlaget Basilisk for tilladelse til at genoptrykke teksten, der foreligger på dansk i ,Borges - en antologi“, Sjakalens Beduinserie, 1983; redigeret og oversat af Per Aage Brandt, Irma Kobæk, Annemarie Salomonsen og Karl Erik Schölhammer. 